\title{
FORMULASI SEDIAAN BLUSH ON DARI PEWARNA ALAMI KOMBINASI EKSTRAK TERONG BELANDA DAN EKSTRAK UMBI BIT MERAH
}

\author{
Zulfikri Zulfikri ${ }^{*}$, Robiatun Rambe ${ }^{2}$, Ratih Paramitha ${ }^{2}$, Sabrina Aufari Harahap ${ }^{2}$ \\ ${ }^{1,2}$ Universitas Haji, Medan, Sumatera Utara, Indonesia \\ Email: fikroa@gmail.com \\ * corresponding author
}

\begin{abstract}
Abstrak
Warna merupakan salah satu faktor penentu mutu pada kosmetika. Penggunaan pewarna sintesis pada blush on dapat menyebabkan perubahan pada warna kulit, iritasi kulit wajah, alergi, iritasi pada saluran pernapasan, dan karsinogenik yang bersumber dari kandungan logam berat pada zat warna sintetis jika digunakan secara terus- menerus. Penggunaan pewarna alami dalam formulasi blush on merupakan salah satu solusi untuk menghindari penggunaan pewarna sintetik yang berbahaya untuk kesehatan. Oleh karena itu, dibuat sediaan blush on dengan menggunakan zat warna alami yaitu kombinasi warna dari ekstrak terong belanda dan ekstrak umbi bit merah yang diperoleh dengan cara maserasi pada masing - masing sampel dengan menggunakan etanol $96 \%$. Tujuan penelitian ini adalah untuk membuat blush on dengan memanfaatkan pewarna alami pada ekstrak terong belanda (Solanum betaceum) dan ekstrak umbi bit merah (Beta vulgaris L). Formula blush on yang dibuat menggunakan zat warna dari kombinasi ekstrak terong belanda dan ekstrak umbi bit merah dengan konsentrasi masing - masing 20\%; kombinasi ekstrak terong belanda $10 \%$ dan ekstrak umbi bit merah 20\%; kombinasi ekstrak terong belanda $20 \%$ dan ekstrak umbi bit merah $10 \%$, sediaan blush on lalu diuji persyaratan mutunya dan warna yang paling disukai oleh panelis. Hasil penelitian dari ketiga sediaan menghasilkan blush on yang homogen, dan daya oles yang baik. $\mathrm{pH}$ sediaan 6 , sediaan tidak mengiritasi dan paling disukai adalah sediaan dengan konsentrasi masing- masing $20 \%$.
\end{abstract}

Kata kunci: terong belanda; umbi bit merah; blush on; pewarna alami; kosmetik

\begin{abstract}
Color is one of the determining factors of cosmetic quality. The use of synthesis dyes on blush can cause skin discoloration, irritation of the facial skin, allergies, irritation of the respiratory tract, and carcinogenic originating from heavy metal content in synthetic dyes if used continuously. The use of natural dyes in the formulation of blush is one solution to avoid the use of synthetic dyes that are harmful to health. Therefore, blush on preparations were made using natural color substances that are a combination of colors of dutch eggplant extract and red beetroot extract. Extracts obtained by maceration, each using ethanol 96\%. The purpose of this study was to make blush by using natural dyes in Dutch eggplant extract (Solanum betaceum) and red beetroot extract (Beta vulgaris L). Blush formula made using color substances from a combination of Dutch eggplant extract and red beetroot extract with a concentration of $20 \%$ each; combination of $10 \%$ dutch eggplant extract and $20 \%$ red beet root extract; combination of dutch eggplant extract $20 \%$ and red beetroot tuber extract 10\%, the blush on preparation is then tested for quality
\end{abstract}


requirements and the color that is most preferred by the panelists. The results of the study of all three preparations produced homogeneous blush, and good oles power. pH preparation 6, the preparation is not irritating and the most preferred is the preparation with a concentration of $20 \%$.

Keywords: dutch eggplant; red beet tubers; blush on; natural dyes; cosmetic.

\section{Pendahuluan}

Blush On merupakan salah satu kosmetika yang biasanya diaplikasikan pada pipi untuk menimbulkan warna kemerahan yang alamisehingga rona wajah kelihatan segar, sehat dan tidak pucat. Blush On konvensional biasanya mengandung pigmen merah atau merah kecoklatan. Umumnya pigmen yang digunakan adalah zat pewarna sintetis.Pewarna berdasarkan sumbernya ada 2 yaitu pewarna alami dan pewarna sintetis. Pewarna alami diperoleh dari buah, bunga, daun dan akar. Pewarna sintetis bersumber dari perpaduan dua atau lebih senyawa kimia yang digunakan sebagai pewarna tambahan pada kosmetika dan makanan (Ayu, 2014).

Pewarna sintetik mempunyai keuntungan yang nyata jika dibandingkan dengan pewarna alami, karena mempunyai kekuatan mewarnai yang lebih kuat, lebih seragam, lebih stabil serta penggunaan lebih praktis dan biasanya lebih murah. tetapi, disamping keuntungan itu semua, pewarna sintetik dapat memberikan efek yang kurang baik pada kesehatan. Penggunaan zat pewarna sintetik pada kosmetik dapat menyebabkan perubahan warna pada kulit, iritasi, alergi, kulit kering dan bisa mengiritasi saluran pernafasan serta bersifat karsinogenik (menyebabkan kanker) yang bersumber dari kandungan logam berat pada zat warna sintetis jika digunakan secara terus- menerus (Syamsuri, 2017).

Penggunaan pewarna alami dalam formulasi blush on merupakan salah satu solusi untuk menghindari penggunaan pewarna sintetik yang berbahaya. Pewarna alami yang bersumber dari tumbuhan antara lain pewarna alami yang bersumber dari terong belanda dan umbi bit merah.

Terong belanda merupakan salah satu tumbuhan yang bisa digunakan sebagai pewarna alami. Zat warna yang terdapat pada buah terong belanda dihasilkan oleh antosianin yang termasuk kedalam golongan flavonoid dan merupakan salah satu jenis antioksidan. Dari hasil penelitian Nurulin Ginni tahun 2019 dan beberapa peneliti sebelumnya, terbukti bahwa terong belanda bisa dijadikan sebagai pewarna alami dan menjadi alternatif pengganti pewarna sintesis.

Umbi bit merah sudah dibudidayakan di seluruh dunia sebagai sumber pangan dan juga berperan dalam pengembangan pewarna merah alami. Warna merah dari bit dihasilkan oleh betasianin (merah) dan betaxantin (kuning) dimana keduanya merupakan kelompok pigmen betalain (betanin). Betalain merupakan pigmen larut air yang mengandung senyawa antioksidan dan anti kanker. Diketahui bahwa umbi bit merah terbukti bisa dijadikan sebagai pewarna alami dan dijadikan alternatif pengganti pewarna sintesis (Nurfitriana D, 2013).

Oleh karena itu peneliti tertarik untuk melakukan penelitian dengan memanfaatkan terong belanda dan umbi bit merahyang kemudian diaplikasikan untuk mengembangkan suatu formulasi blush on sebagai zat pewarna alami. 


\section{Metode Penelitian}

Alat: Alat-alat yang digunakan dalam penelitian ini ialah Rotary evaporator, $\mathrm{pH}$ universal, cawan penguap, kertas saring, timbangan, batang pengaduk, lumpang dan alu, pipet tetes, tissue, kertas perkamen, spatula, sudip, wadah blushon, dan toples.

Bahan : Bahan-bahan yang akan digunakan antara lain: ekstrak terong belanda, ekstrak umbi bit merah, etanol 96\%, talkum, kaolin, lanolin, isopropil miristat, nipagin, zink oksida, dan aquadest.

Sukarelawan : Sukarelawan yang dijadikan panel pada uji iritasi dan uji kesukaan dalam pembuatan kombinasi pewarna alami blush on dari ekstrak terong belanda (Solanum betaceum) dan ekstrak umbi bit merah (Beta vulgaris $L$ ) berjumlah 10 orang uji kesukaan dan 10 orang untuk uji iritasi dengan kriteria untuk uji iritasi

Prosedur Percobaan :

Ekstraksi Terong Belanda : Timbang terong belanda $500 \mathrm{~g}$ yang sudah dibersihkan, dihaluskan dan dimaserasi menggunakan etanol 96\% sebanyak 5 liter. Diamkan selama 5 hari sambil diaduk - aduk. Saring dan tampung filtratnya. Masukkan kedalam wadah tertutup rapat. Diamkan selama 2 hari ditempat sejuk dan terlindung dari cahaya. Uapkan ekstrak menggunakan rotary evaporator.

Ekstraksi Umbi Bit Merah : Timbang umbi bit merah $500 \mathrm{~g}$ yang sudah dibersihkan dan dipisah dari kulitnya, dimaserasi menggunakan etanol $96 \%$ sebanyak 5 liter, didiamkan selama 5 hari, lalu disaring menggunakan kertas saring dan diuapkan menggunakan rotary evaporator untuk mendapatkan ekstrak kental(Bu'ulolo, 2019).

\section{Formulasi Blush On :}

Tabel 1. Formula Kombinasi Blush On dari Ekstrak Terong Belanda dan Ekstrak Umbi Bit Merah

\begin{tabular}{lcccc}
\hline \multirow{2}{*}{ Komposisi } & \multicolumn{4}{c}{ Konsentrasi (gram) } \\
\cline { 2 - 5 } & $\mathbf{F}_{\mathbf{0}}$ & $\mathbf{F}_{\mathbf{1}}$ & $\mathbf{F}_{\mathbf{2}}$ & $\mathbf{F}_{\mathbf{3}}$ \\
\hline Zat Warna Ekstrak Terong & $0 \%$ & $20 \%$ & $10 \%$ & $20 \%$ \\
$\begin{array}{l}\text { Belanda } \\
\text { Zat warna ekstrak Umbi Bit }\end{array}$ & $0 \%$ & $20 \%$ & $20 \%$ & $10 \%$ \\
Merah & 2 & & & \\
Kaolin & 1 & 1 & 2 & 2 \\
Zink Oksida & 1 & 1 & 1 & 1 \\
Lanolin & 0,02 & 0,02 & 0,02 & 0,02 \\
Isopropyl miristrat & 0,02 & 0,02 & 0,02 & 0,02 \\
Nipagin & 0,02 & 0,02 & 0,02 & 0,02 \\
Parfum & 3,94 & 0.74 & 1,54 & 1,54 \\
Talkum & $\mathbf{8 ~ g}$ & $\mathbf{8 ~ g}$ & $\mathbf{8 ~ g}$ & $\mathbf{8} \mathbf{g}$ \\
Total & & &
\end{tabular}

Keterangan :

$\mathrm{F}_{0}$ : Formulasi tanpa ekstrak terong belanda dan ekstrak umbi bit merah

$\mathrm{F}_{1}$ : Formulasi dengan konsentrasi ekstrak terong belanda dan ekstrak umbi bit merah masing - masing $20 \%$

$\mathrm{F}_{2}$ : Formulasi dengan konsentrasi 10\% ekstrak terong belanda dan 20\% ekstrak umbi bit merah

$\mathrm{F}_{3}$ : Formulasi dengan kombinasi konsentrasi $20 \%$ ekstrak terong belanda dan $10 \%$ ekstrak umbi bit merah 


\section{Prosedur Pembuatan Blush On :}

Masing-masing bahan serbuk seperti kaolin, talkum, zink oksida, dan nipagin ditimbang kemudian digerus homogen didalam lumpang, kemudian dimasukkan lanolin dan zat pengikat isopropil miristat pada cawan lalu lebur diatas penangas air kemudian dimasukkan semua serbuk, ekstrak terong belanda (Solanum betaceum) dan ekstrak umbi bit merah (Beta vulgaris L) diaduk sampai dengan homogen, ditambahkan parfum lalu dimasukkan kedalam wadah.

\section{Uji Homogenitas}

Blush On dioleskan pada sekeping kaca atau bahan transparan lain yang cocok, sediaan harus menunjukkan susunan homogen yang tidak terlihat adanya butiran kasar (Farmakope Edisi III, 1979).

\section{Uji pH}

Pengukuran $\mathrm{pH}$ dilakukan dengan menggunakan alat pengukur $\mathrm{pH}$. Syarat $\mathrm{pH}$ sediaan pemerah pipi yang baik sesuai dengan $\mathrm{pH}$ kulit secara umum adalah 4-7 (Wasitaatmadja, 1997).

\section{Uji Poles}

Uji poles dilakukan terhadap masing- masing sediaan dengan cara dipoleskan lima kali pada punggung telapak tangan dan diamati warnanya (Keithler, 1956).

\section{Uji Hedonik}

Uji kesukaan dilakukan untuk mengetahui tingkat kesukaan panelis terhadap sediaan yang dibuat.

\section{Uji Iritasi}

Uji iritasi dilakukan untuk mengetahui bahwa sediaan yang dibuat dapat menimbulkan iritasi pada kulit atau tidak.

\section{Hasil dan Pembahasan}

\section{Hasil Ekstraksi}

Proses pembuatan ekstrak terong belanda dan umbi bit merah menggunakan metode maserasi. Maserasi dipilih karena baik untuk senyawa - senyawa yang tidak tahan terhadap panas dan memiliki keuntungan diantaranya peralatan yang digunakan sederhana dan proses pengerjaan yang mudah. Ekstrak kental yang diperoleh pada terong belanda sebanyak 44.5 gr dan umbi bit merah sebanyak 30.44 gr. Hasil ekstrak kental yang diperoleh dari kedua sample yang berbeda kemungkinan disebabkan kandungan air dari terong belanda lebih banyak dari umbi bit merah yaitu sebesar 80-90 gr/tiap $100 \mathrm{gr}$ sedangkan umbi bit merah sebesar 87,58 gr/tiap 100 gr. Warna dari ekstrak terong belanda berwarna merah maroon, sedangkan warna dari ekstrak kental umbi bit merah berwarna coklat kehitaman, warna menjadi gelap karena terjadi nya gula invert. Gula invert adalah gula yang dihasilkan melalui hidrolisis atau pemecahan sukrosa menjadi dua bagian yaitu glukosa dan fruktosa. Terjadinya gula invert dikarenakan sample melalui proses pemanasan (Tim MGMP, 2015).

\section{Hasil Formula Blush On}

Sediaan dengan perbandingan konsentrasi 1 : 1 ekstrak terong belanda dengan ekstrak umbi bit merah menghasilkan warna ungu, dikarenakan perbandingan konsentrasi dari masing masing ekstrak kental sama dan dipengaruhi oleh warna dari bahan basis yang digunakan. Sediaan dengan perbandingan konsentrasi $1: 2$ ekstrak terong belanda dengan ekstrak umbi bit merah menghasilkan warna ungu 
kecoklatan, dikarenakan konsentrasi dari umbi bit merah lebih besar dan mendominasi sediaan, juga dipengaruhi oleh warna dari bahan basis yang digunakan. Sediaan dengan perbandingan konsentrasi $2: 1$ ekstrak terong belanda dengan ekstrak umbi bit merah mengahasilkan warna ungu tua, dikarenakan konsentrasi ekstrak terong belanda lebih besar dan mendominasi sediaan, juga dipengaruhi oleh warna dari bahan basis yang digunakan.Sebagai pembanding digunakan blush on yang beredar dipasaran dengan merk Emina yang berwarna ungu muda. Pewarna yang digunakan yaitu pewarna sintetik dengan kode CI 15850;1 pigmen red 57.

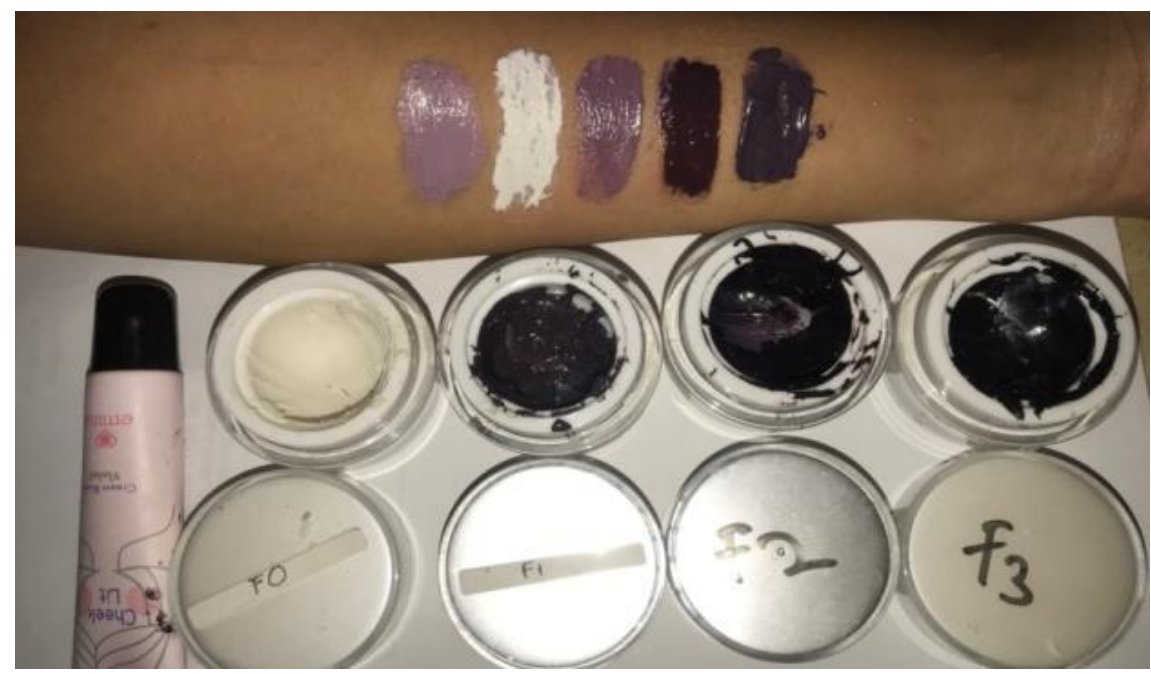

Gambar 1. Hasil Formula Blush On dan Perbandingan dengan Blush on dipasaran

\section{Hasil Uji Homogenitas}

Tabel 2. Hasil Uji Homogenitas

\begin{tabular}{cl}
\hline Formula & Homogen \\
\hline F0 & Homogen \\
F1 & Homogen \\
F2 & Homogen \\
F3 & Homogen \\
\hline
\end{tabular}

Hasil pemeriksaan dispersi warna menunjukkan bahwa sediaan yang dibuat terdispersi merata dan tidak ada warna yang berbeda atau tidak merata pada saat dioleskan pada objek glass. 


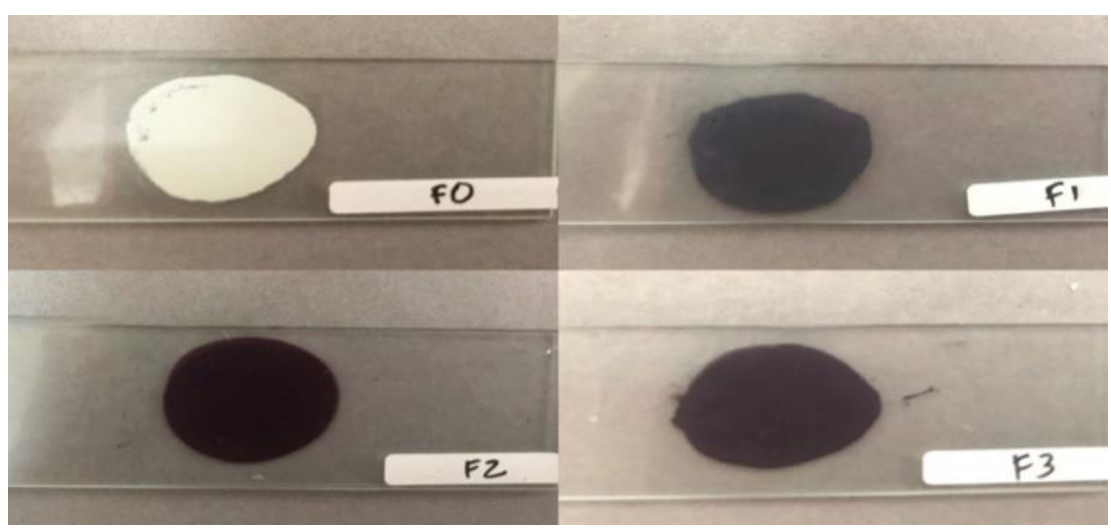

Gambar 2. Hasil Uji Homogenitas

\section{Hasil Uji pH}

Tabel 3. Hasil Uji pH

\begin{tabular}{cc}
\hline Formula & Nilai pH \\
\hline F0 & 5 \\
F1 & 6 \\
F2 & 6 \\
F3 & 6 \\
\hline
\end{tabular}

Dari hasil penelitian diperoleh, ketiga formula yang diuji menunjukkan $\mathrm{pH}$ yang sama yaitu 6 . Syarat $\mathrm{pH}$ sediaan pemerah pipi yang baik sesuai dengan $\mathrm{pH}$ kulit secara umum adalah 4-7 (Wasitaatmadja, 1997). Dengan demikian pH sediaan blush on yang diformulasikan memenuhi persyaratan yang diizinkan.

\section{Hasil Uji Oles}

Berdasarkan hasil uji poles diperoleh bahwa sediaan menghasilkan pemolesan yang baik. Hal ini ditandai setelah sekali pemolesan sediaan telah memberikan warna yang jelas saat dipoleskan pada kulit punggung tangan.

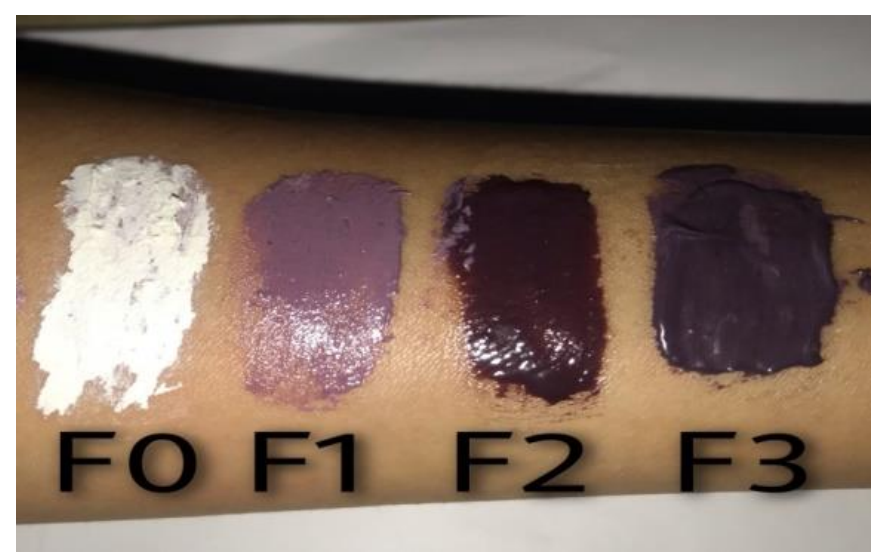

Gambar 3. Hasil Uji Poles 


\section{Hasil Uji Hedonik}

Data yang diperoleh dari 10 orang panelis dan ditentukan nilai kesukaannya untuk setiap sediaan dengan tingkat kepercayaan $95 \%$.

Tabel 4. Hasil Uji Hedonik

\begin{tabular}{lccc}
\hline Formula & Sangat Suka & Suka & Kurang Suka \\
\hline F0 & - & - & - \\
F1 & 7 & 2 & 1 \\
F2 & 2 & 5 & 3 \\
F3 & 1 & 5 & 4 \\
\hline
\end{tabular}

Berdasarkan hasil yang diperoleh bahwa sediaan F1 yang menghasilkan warna ungu paling banyak disukai oleh panelis yaitu sebanyak 7 dari 10 panelis, karena warna sediaan F1 yang paling cerah diantara sediaan lainnya.

\section{Hasil Uji Iritasi}

Hasil uji iritasi yang telah dioleskan pada kulit lengan bawah bagian dalam terhadap 10 orang panelis selama kurang lebih 24 jam menunjukkan bahwa tidak ada sediaan blush on dari keempat formula yang menyebabkan iritasi. Hal ini ditandai dengan tidak ditemukan nya eritema, papula, vesikula dan edema.

\section{Kesimpulan}

Dari hasil penelitian dapat disimpulkan bahwa, sediaan kombinasi ekstrak terong belanda (Solanum betaceum) dan ekstrak umbi bit merah (Beta vulgaris L) bisa digunakan sebagai pewarna alami dalam formulasi sediaan blush on. Variasi konsentrasi pewarna kombinasi ekstrak terong belanda (Solanum betaceum) dan ekstrak umbi bit merah (Beta vulgaris $L$ ) yang digunakan dalam formulasi menghasilkan perbedaan intensitas warna pada sediaan blush on. Sediaan dengan konsentrasi masing masing $20 \%$ menghasilkan warna ungu, sediaan dengan konsentrasi ekstrak terong belanda $20 \%$ dengan ekstrak umbi bit merah $10 \%$ menghasilkan warna ungu kecoklatan dan sediaan ekstrak terong belanda 10\% dengan ekstrak umbi bit merah $20 \%$ menghasilkan warna ungu tua. Hasil uji homogenitas, uji $\mathrm{pH}$, dan uji iritasi semuanya memenuhi standart persyaratan yang sudah ditentukan. Hasil uji hedonik yang dilakukan terhadap 10 orang panelis menunjukkan bahwa Formula 1 paling banyak disukai oleh panelis. 


\section{Referensi}

Anonim. (1979). Farmakope Indonesia, Edisi III. Jakarta: Departemen Kesehatan Republik Indonesia.

Ayu,G.S. (2014). The Complete Beauty Book. Yogyakarta: Kanal Publika.

Bu'ulolo, P. (2019). Formulasi Sediaan Pemerah Pipi Kombinasi Ekstrak Umbi Bit Merah (Beta vulgaris L) dan Ekstrak Angkak Dalam Bentuk Stick. Program Studi Sarjana Farmasi. Fakultas Farmasi dan Kesehatan. Medan: Institut Kesehatan Helvetia Medan.

Keithler, W. R. (1956). The Formulation of Cosmetics dan Cosmetic Specialities. New York: Drug and Cosmetic Industry. Hal. 153 - 155.

Nurfitriana, D., Leni. P., \& Ratih A. (2013). Formulasi Blush On Cream Menggunakan Pewarna Alami Umbi Bit Merah (Beta Vulgaris L.).Prodi Farmasi. Fakultas Matematika dan Ilmu Pengetahuan Alam. Universitas Islam Bandung.

Siregar, N.G.L.A. (2019). Formulasi Blush On Menggunakan Ekstrak Buah

Terong Belanda (Solanum betaceum Cav.) Sebagai Pewarna Alami dan Blush On Merek Emina Sebagai Pembanding. Jurusan Farmasi. Politeknik Kesehatan Kemenkes Medan.

Syamsuri, S. (2017). Analisis Kandungan Rhodamin B sebagai Pewarna pada Sediaan Lipstik Impor yang Beredar di Kota Makassar. Jurusan Fakultas Ilmu Kesehatan. Universitas Islam Negeri Alauddin Makassar.

Tim MGMP Pati. (2015). Ilmu Resep Teori Jilid II. Yogyakarta: Deepublish.

Wasitaatmadja, S. M. (1997). Penuntun Kosmetik Medik. Jakarta: Universitas Indonesia Press. 